\title{
Betawi Adolescents' Language Attitudes Towards Their Mother Tongue: A Sociolinguistic Perspective in Indonesia
}

\author{
Tadjuddin Nur,
}

\author{
${ }^{1}$ Jakarta National University \\ *Corresponding author. Email: Tadjuddin.kwardadki@gmail.com
}

\begin{abstract}
This study was aimed to examine the attitude of Betawi adolescents towards their mother tongue, the Indonesian, and foreign languages influence on using mother tongue for communication. This employed a descriptive quantitative design with a sociolinguistic approach. The respondents were drawn from cities within the Jakarta province, including Central Jakarta, North Jakarta, West Jakarta, East Jakarta, South Jakarta, and the border areas such as Bekasi, Tangerang, and Depok. Additionally, questionnaires were used to collect data from a sample size of 120 Betawi adolescents spread across the city. Lambert's theory, which states that the attitude consists of cognitive (knowledge), affective (judgmental), and conative (behavior) aspects, was used to describe and interpret the data collected. From the results, it was concluded that the attitude of Betawi adolescents towards their mother tongue was negative, the Indonesian influenced shifting the mother tongue, and finally, foreign languages had no influence on shifting from their mother tongue.
\end{abstract}

Keywords: language attitudes, adolescents, mother tongue.

\section{INTRODUCTION}

Many experts, specifically in the field of social psychology, conducted studies on attitude. Triandis [1] argued that attitude is the readiness to react in an encountered situation or event. Fundamentally, it is considered as a person's readiness to deal with a situation mentally. Furthermore, Anderson, (2010) suggested two types of attitudes, including linguistic and non-linguistic, related to cognition or beliefs about a certain language. Therefore, language attitude can be termed as long-term belief or cognition about language or language objects, which influences a person to react in a certain way.

Although people embrace their native language, external influence, specifically association with elite groups such as the political class, economically endowed persons, and the social-cultural class, might negatively impact its perception. For instance, most people copy the languages of the ethnicities, which are considered successful economically, politically, and socially. In such a situation, people express a positive view of the second language and negatively look down upon their mother tongue [2].

Lambert [3] stated that attitude consists of cognitive, affective, and conative aspects. Cognitive aspects are related to knowledge about the environment and the ideas used in the thinking process. The affective factor involves judging whether someone, something, or a situation is welcome or not. Also, the conative aspect is concerned with the behavior or actions as the final decision on reactive readiness to a situation.

Adolescence is the transition period from childhood to adulthood characterized by the beginning of physical and social-psychological maturity. The adolescent age period is categorized into two, including 10-14 years, essentially referred to early adolescence, and 15-20 years or late adolescence group. According to the Indonesian Central Statistics Agency, the age limit for adolescents is $15-24$ years, which is close to the one set by the United Nations on youth.

According to WHO (1974), adolescents experience biological, psychological, and socioeconomic changes as they transit. Biological changes are different within 
individuals, but the majority exhibit similar physical changes such as an increase in height, gaining muscle mass, distribution of body fat, and developing secondary sexual signs. Psychological changes involve personal identification, solving individual problems, abstract thinking, and recognizance of other people's opinions. Additionally, the socioeconomic changes refer to the transition experienced by adolescents from full socioeconomic dependence to a relatively more independent state Sarwono, [4].

Mother tongue is the first language, which people master daily to convey thoughts, feelings, and the needs of life. It is universally embodied with Wierzbicka as a "natural semantic metal language," a subsection of the complete natural language [5]. Concisely, the wealth of a nation is reflected through the variety of the local languages it has. In Indonesia, the local language is central to preserve cultural heritage, therefore, many educational programs support the use of the mother tongue [6].

The use of Indonesian as the official language in schools has led to the drastic fall of local dialects, specifically among adolescents. Furthermore, the use of English or other foreign languages is considered more prestigious and provides greater value than native languages. The influence of these languages has resulted to most Betawi adolescents forsaking their mother tongue. This has threatened extinction of Betawi language because of the following reasons. First, the parents are no longer accustomed to speak Betawi to their children. Second, the community extensively uses Indonesian in their daily communication in place of the local dialect. Third, the Betawi language is not taught in schools as a local content subject, and efforts to maintain the language by the Jakarta Provincial Government are only limited to rhetoric and rules that are not yet implemented. Therefore, this study aimed to describe the Betawi adolescents' language attitude towards their mother tongue in cognitive, behavioral, and affective aspects.

\section{METHODOLOGY}

\subsection{Study Area}

This study adopted a sociolinguistic approach with a quantitative data collection technique. The data was collected within the cities of Jakarta, including Central Jakarta, North Jakarta, West Jakarta, East Jakarta, South Jakarta, and the border areas such as Bekasi, Tangerang, and Depok. These regions were considered as the areas of residence for the Betawi people. A total of 120 adolescents were identified and randomly selected as the main population target for the study.

\subsection{Data Collection}

The questionnaires with interrogations arranged according to the study objectives were issued to the participants for data collection. The arrangement was based on Lambert's theory that identified attitude in terms of cognitive (knowledge), affective (judgmental), and conative (behavior) aspects. The PASW Statistics program was used to analyze data and the findings discussed in the context of Lambert's theory.

\section{RESULTS AND DISCUSSION}

\subsection{Betawi Adolescent's Language Attitude towards Mother Language}

Betawi adolescents' language attitude towards their mother tongue was analyzed based on Lambert's theory. The results confirmed that adolescents put into action whatever they learn, which becomes a tangible manifestation of understanding. Therefore, people try to guess a person's attitude towards a given situation through these three aspects analyzed below.

\subsubsection{Cognitive Aspect}

In this aspect, five indicators were analyzed, including identity, the use of everyday language in the family, language transmission, the language taught in schools as local content subjects, and the use of Betawi language among adolescents, as illustrated in (Table 1) below.

Table 1. Respondents' Responses to Cognitive Aspect

\begin{tabular}{|c|c|c|c|c|c|c|c|c|c|c|}
\hline $\begin{array}{c}\text { Indicator } \\
\text { Code }\end{array}$ & Statement & $\begin{array}{l}\mathrm{F} \\
\% \\
\end{array}$ & STS & TS & $\mathrm{RR}$ & S & SS & Total & $\begin{array}{l}\text { Total } \\
\text { Score } \\
\end{array}$ & \begin{tabular}{|l|} 
Ideal \\
Score \\
\end{tabular} \\
\hline \multirow{2}{*}{ KO1 } & \multirow{2}{*}{$\begin{array}{l}\text { The Betawi language shows } \\
\text { the identity of the Betawi } \\
\text { people }\end{array}$} & $F$ & 22 & 72 & 24 & \begin{tabular}{|l}
2 \\
\end{tabular} & 0 & 120 & 246 & \multirow[b]{2}{*}{600} \\
\hline & & $\%$ & 18.3 & 60 & 20 & 1.67 & 0 & 100 & 41.00 & \\
\hline \multirow[b]{2}{*}{ KO2 } & \multirow{2}{*}{$\begin{array}{l}\text { The Betawi language is a } \\
\text { means of daily } \\
\text { communication in the } \\
\text { family }\end{array}$} & $F$ & 18 & 56 & 44 & 2 & 0 & 120 & 270 & \multirow[b]{2}{*}{600} \\
\hline & & $\%$ & 15 & 46.7 & 36.7 & 1.67 & 0 & 100 & 45.00 & \\
\hline \multirow[b]{2}{*}{ KO3 } & \multirow{2}{*}{$\begin{array}{l}\text { Language } \begin{array}{r}\text { transmission } \\
\text { from parents } \\
\text { children }\end{array} \text { their } \\
\text { chen }\end{array}$} & $F$ & 20 & 71 & 25 & 4 & 0 & 120 & 253 & \multirow[b]{2}{*}{600} \\
\hline & & $\%$ & 16.7 & 59.2 & 20.8 & 3.33 & 0 & 100 & 42.17 & \\
\hline \multirow[b]{2}{*}{ KO4 } & \multirow{2}{*}{$\begin{array}{l}\text { The Betawi language is } \\
\text { taught in schools as a local } \\
\text { content subject }\end{array}$} & $\mathrm{F}$ & 21 & 74 & 22 & 3 & 0 & 120 & 247 & \multirow[b]{2}{*}{600} \\
\hline & & $\%$ & 17.5 & 61.7 & 18.3 & 2.5 & 0 & 100 & 41.17 & \\
\hline \multirow[b]{2}{*}{ KO5 } & \multirow{2}{*}{$\begin{array}{l}\text { The Betawi language is } \\
\text { used by adolescents in their } \\
\text { daily interactions }\end{array}$} & $\mathrm{F}$ & \begin{tabular}{|l|}
31 \\
\end{tabular} & 68 & 18 & 3 & 0 & 120 & 233 & \multirow[b]{2}{*}{600} \\
\hline & & $\%$ & 25.8 & 56.7 & 15 & 2.5 & 0 & 100 & 38.83 & \\
\hline \multicolumn{9}{|l|}{$\begin{array}{l}\text { Total } \\
\text { Percen }\end{array}$} & 1,249 & \multirow{2}{*}{3.000} \\
\hline Percent & & & & & & & & & 41.63 & \\
\hline
\end{tabular}

The expected score for the responses from the questionnaires on cognitive aspects was 3,000. However, the calculation showed the total value obtained was $1,249(41.63 \%)$ of the ideal score, with all indicators recording below 50\%. The results showed that the KO2 indicator had the highest score of $45 \%$, indicating that the Betawi language was used daily in family communication.

Based on the analysis, it was concluded that respondents (Betawi adolescents) showed a negative language attitude in the cognitive aspect as evidenced from all the indicators, which were below $50 \%$. Additionally, the cognitive aspect related to knowledge taught by parents to their children and in schools proved to have a negative perception. 


\subsubsection{Cognitive Aspect}

Five indicators including a sense of pride in the Betawi language, the use of the Betawi language, and the benefits of the Betawi language used to explain the affective aspect, were presented as shown in (Table 2) below.

Table 2. Respondents' Responses to Affective Aspect

\begin{tabular}{|c|c|c|c|c|c|c|c|c|c|c|}
\hline $\begin{array}{l}\text { Indicator } \\
\text { Code }\end{array}$ & Statement & $\frac{\mathrm{F}}{\%}$ & STS & TS & $\mathrm{RR}$ & S & SS & Total & $\begin{array}{l}\text { Total } \\
\text { Score }\end{array}$ & $\begin{array}{l}\text { Ideal } \\
\text { Score }\end{array}$ \\
\hline \multirow{2}{*}{$\mathrm{AF} 1$} & \multirow{2}{*}{$\begin{array}{l}\text { I feel proud if I } \\
\text { communicate using the } \\
\text { Betawi language }\end{array}$} & $\mathrm{F}$ & 24 & 68 & 25 & 3 & 0 & 120 & 247 & \multirow[b]{2}{*}{600} \\
\hline & & $\%$ & 20 & 56.7 & 20.8 & 2.5 & 0 & 100 & 41.17 & \\
\hline \multirow[b]{2}{*}{$\mathrm{AF} 2$} & \multirow{2}{*}{$\begin{array}{l}\text { I find it easier to master } \\
\text { Betawi vocabulary than } \\
\text { Indonesian }\end{array}$} & $F$ & 37 & 71 & 12 & 0 & 0 & 120 & 215 & \multirow[b]{2}{*}{600} \\
\hline & & $\%$ & 30.8 & 59.2 & 10 & 0 & 0 & 100 & 35.83 & \\
\hline \multirow[b]{2}{*}{$\mathrm{AF} 3$} & \multirow{2}{*}{$\begin{array}{l}\text { The Betawi language is } \\
\text { more useful than the } \\
\text { Indonesian }\end{array}$} & $F$ & 25 & 60 & 25 & 10 & 0 & 120 & 260 & \multirow[b]{2}{*}{600} \\
\hline & & $\%$ & 20.8 & 50 & 20.8 & 8.33 & 0 & 100 & 43.33 & \\
\hline \multirow{2}{*}{$\mathrm{AF} 4$} & \multirow{2}{*}{$\begin{array}{l}\text { By mastering the Betawi } \\
\text { language, my self- } \\
\text { esteem increases }\end{array}$} & $\mathrm{F}$ & 24 & 72 & 22 & 2 & 0 & 120 & 242 & \multirow[b]{2}{*}{600} \\
\hline & & $\%$ & 20 & 60 & 18.3 & 1.67 & 0 & 100 & 40.33 & \\
\hline \multirow[b]{2}{*}{ AF5 } & It's easier for me to & $\mathrm{F}$ & 32 & 75 & 13 & 0 & 0 & 120 & 221 & \multirow[b]{2}{*}{600} \\
\hline & $\begin{array}{l}\text { understand information } \\
\text { if I use the Betawi } \\
\text { language }\end{array}$ & $\%$ & 26.7 & 62.5 & 10.8 & 0 & 0 & 100 & 36.83 & \\
\hline \multicolumn{9}{|l|}{ Total } & $\begin{array}{l}1.185 \\
3950\end{array}$ & 3,000 \\
\hline
\end{tabular}

The expected score for responses on affective aspects was 3,000. However, the calculation showed that the total value obtained was $1.185(39.50 \%)$ of the ideal score. Furthermore, all the indicators recorded a score below 50\%, with the AF3 at the top with $43.33 \%$. This was an indication that Betawi was more useful than the Indonesian language. The second-highest score involved AF1 with $41.17 \%$, which explained that the respondents were proud of using the Betawi language to communicate.

In conclusion, the average score of all indicators was below $50 \%$, indicating that the respondents had a negative attitude towards the affective aspect. Further, the affective aspect that concerns judging whether the adolescents were proud of the Betawi language and its benefits were negatively exhibited.

\subsubsection{Conative Aspect}

Five indicators were considered, including the use of Betawi language in communication with family, neighborhood communication, formal situation communication, social media communication, and communication in recitation activities, as shown in Table 3 below.

Table 3. Respondents' Responses to Conative Aspect

\begin{tabular}{|c|c|c|c|c|c|c|c|c|c|c|}
\hline $\begin{array}{l}\text { Indicator } \\
\text { Code }\end{array}$ & Statement & $\begin{array}{c}\mathrm{F} \\
\%\end{array}$ & STS & TS & $\mathrm{RR}$ & S & SS & Total & $\begin{array}{l}\text { Total } \\
\text { Score }\end{array}$ & \begin{tabular}{|l|} 
Ideal \\
Score
\end{tabular} \\
\hline & I often use the Betawi & $\mathrm{F}$ & 36 & 73 & 11 & 0 & 0 & 120 & 215 & \\
\hline KON1 & $\begin{array}{l}\text { language in } \\
\text { communicating with my } \\
\text { family }\end{array}$ & $\%$ & 30 & 60.8 & 9.17 & 0 & 0 & 100 & 35.83 & 600 \\
\hline \multirow[b]{2}{*}{ KON2 } & I often use the Betawi & $\mathrm{F}$ & 24 & 73 & 21 & 2 & 0 & 120 & 241 & \multirow[b]{2}{*}{600} \\
\hline & $\begin{array}{l}\text { language in } \\
\text { communicating with my } \\
\text { neighbors }\end{array}$ & $\%$ & 20 & 60.8 & 17.5 & 1.67 & 0 & 100 & 40.17 & \\
\hline \multirow[b]{2}{*}{ KON3 } & I often use the Betawi & $\mathrm{F}$ & 24 & 66 & 29 & 1 & 0 & 120 & 247 & \multirow[b]{2}{*}{600} \\
\hline & $\begin{array}{l}\text { language in } \\
\text { communicating in formal } \\
\text { situations }\end{array}$ & $\%$ & 20 & 55 & 24.2 & 0.83 & 0 & 100 & 41.17 & \\
\hline \multirow{2}{*}{ KON4 } & I often use the Betawi & F & 20 & 65 & 34 & 1 & 0 & 120 & 256 & \multirow[b]{2}{*}{600} \\
\hline & $\begin{array}{l}\text { language in interacting } \\
\text { on social media }\end{array}$ & $\%$ & 16.7 & 54.2 & 28.3 & 0.83 & 0 & 100 & 42.67 & \\
\hline \multirow[b]{2}{*}{ KON5 } & I often use the Betawi & $\mathrm{F}$ & 15 & 77 & 28 & 0 & 0 & 120 & 253 & \multirow[b]{2}{*}{600} \\
\hline & $\begin{array}{l}\text { language in my recitation } \\
\text { activities }\end{array}$ & $\%$ & 12.5 & 64.2 & 23.3 & 0 & 0 & 100 & 42.17 & \\
\hline \multicolumn{9}{|l|}{$\begin{array}{l}\text { Total } \\
\text { Percentage }\end{array}$} & $\frac{1,212}{40.40}$ & 3,000 \\
\hline
\end{tabular}

The expected score for responses on the conative aspect was 3,000. However, the calculation showed the total value obtained was $1,212(40.40 \%)$ of the ideal score. Typically, all indicators scored below $50 \%$, with the KON4 indicator taking the lead of $42.67 \%$, indicating that respondents often use the Betawi language in their interactions.

Based on the analysis, it was concluded that the respondents showed a negative language attitude in the conative aspect. Moreover, the conative aspect regarding behavior or actions as reactive readiness towards using the Betawi language in every situation had a negative score.

The analysis shows that cognitive, affective, and conative aspects of language are closely related. However, a person's social experience is the cause of inconsistency exhibited in the three aspects. In this study, the relationship among the three aspects is close to predict that behavior influences attitude.

\subsection{The Influence of Indonesian on Mother Tongue}

Language shift and maintenance can be likened to the two sides of a coin. In the same way, language cannot defend itself, therefore, it keeps shifting. The choice of language has long-term effects (at least three generations) and is collective (performed by all community members). Holmes, (2001,1992) suggested that economic, social, political, demographic, behavioral, and value factors promote language shifts. Furthermore, Sumarsono, (2017) stated that bilingualism, migration, economy, and education cause language shifts. According to Susan Gal, (1979) the factors that influence language shift are economy, religion, age, differences in prestige, and ambivalent attitudes.

Table 4 presents the analysis of 9 indicators regarding the attitude of Betawi adolescents towards shifting to the Indonesian language from their mother tongue.

Table 4. Respondents' Responses to Indonesian Variables

\begin{tabular}{|c|c|c|c|c|c|c|c|c|c|c|}
\hline $\begin{array}{l}\text { Indicator } \\
\text { Code }\end{array}$ & Statement & \begin{tabular}{c|c}
$\mathrm{F}$ \\
$\%$
\end{tabular} & STS & TS & $\mathrm{RR}$ & $\mathrm{s}$ & ss & Total & $\begin{array}{l}\text { Total } \\
\text { Score }\end{array}$ & $\begin{array}{l}\text { Ideal } \\
\text { Score }\end{array}$ \\
\hline \multirow[b]{2}{*}{ BHS1 } & \multirow{2}{*}{$\begin{array}{l}\text { The Indonesian language shows } \\
\text { my identity as the Indonesian } \\
\text { Nation }\end{array}$} & F & 3 & 7 & 24 & 77 & 9 & 120 & 442 & \multirow[b]{2}{*}{600} \\
\hline & & $\%$ & 2.5 & 5,83 & 20 & $\begin{array}{c}64 \\
2\end{array}$ & 7,5 & 100 & 73,67 & \\
\hline \multirow[b]{2}{*}{ BHS2 } & \multirow{2}{*}{$\begin{array}{l}\text { Indonesian as a means of daily } \\
\text { communication in the family }\end{array}$} & F & 3 & 9 & 27 & 77 & 4 & 120 & 430 & \multirow[b]{2}{*}{600} \\
\hline & & $\%$ & 2.5 & 7,5 & 22,5 & 64 & 3,3 & 100 & 71,67 & \\
\hline \multirow[b]{2}{*}{ BHS3 } & \multirow{3}{*}{$\begin{array}{l}\text { The government carries out the } \\
\text { preservation of the Indonesian } \\
\text { language with real programs }\end{array}$} & $\mathrm{F}$ & 5 & 15 & 30 & 63 & 7 & 120 & 112 & \multirow[b]{2}{*}{600} \\
\hline & & $\%$ & 4,17 & 12,5 & 25 & $\begin{array}{l}52 \\
.5\end{array}$ & $\begin{array}{l}5,8 \\
3\end{array}$ & 100 & 68,67 & \\
\hline \multirow[b]{2}{*}{ BHS4 } & & $\mathrm{F}$ & 0 & 10 & 36 & 64 & 10 & 120 & 434 & \multirow[b]{2}{*}{600} \\
\hline & \multirow{2}{*}{$\begin{array}{l}\text { I feel proud if I communicate using } \\
\text { Indonesian }\end{array}$} & $\%$ & 0 & 8,33 & 30 & $\begin{array}{l}53 \\
3\end{array}$ & $\begin{array}{l}8,3 \\
3\end{array}$ & 100 & 72,33 & \\
\hline \multirow[b]{2}{*}{ BHS5 } & & $\mathrm{F}$ & 0 & 13 & 46 & 57 & 4 & 120 & 412 & \multirow[b]{2}{*}{600} \\
\hline & $\begin{array}{l}\text { I find it easier to master Indonesian } \\
\text { vocabulary than Betawi }\end{array}$ & $\%$ & 0 & 10,8 & 38,3 & $\begin{array}{l}47 \\
.5\end{array}$ & $\begin{array}{l}3,3 \\
3\end{array}$ & 100 & 68,67 & \\
\hline \multirow[b]{2}{*}{ BHS6 } & \multirow[b]{2}{*}{$\begin{array}{l}\text { It is easier for me to understand } \\
\text { information if I use Indonesian }\end{array}$} & $\mathrm{F}$ & 0 & 3 & 32 & 75 & 6 & 120 & 46 & \multirow[b]{2}{*}{600} \\
\hline & & $\%$ & 0 & 4,17 & 26,7 & $\begin{array}{c}62 \\
.5\end{array}$ & 6,6 & 100 & 74,33 & \\
\hline \multirow[b]{2}{*}{ BHS7 } & \multirow[b]{2}{*}{$\begin{array}{l}\text { I often use Indonesian in } \\
\text { communicating with my family }\end{array}$} & $\mathrm{F}$ & 2 & 10 & 45 & 59 & 1 & 120 & 413 & \multirow[b]{2}{*}{600} \\
\hline & & $\%$ & 1,67 & 8,33 & 37,5 & $\begin{array}{l}49 \\
.2\end{array}$ & 3,3 & 100 & 68,83 & \\
\hline \multirow[b]{2}{*}{ BHS8 } & \multirow{2}{*}{$\begin{array}{l}\text { I often use Indonesian in } \\
\text { communicating } \\
\text { situations }\end{array}$} & $\mathrm{F}$ & 2 & 22 & 62 & 28 & 6 & 120 & 374 & \multirow[b]{2}{*}{600} \\
\hline & & $\%$ & 1,67 & 18,3 & 51,7 & $\begin{array}{c}23 \\
3\end{array}$ & 5 & 100 & 62,33 & \\
\hline \multirow[b]{2}{*}{ BHS9 } & \multirow[b]{2}{*}{$\begin{array}{l}\text { I often use Indonesian when } \\
\text { interacting on social media }\end{array}$} & $\mathrm{F}$ & 0 & 2 & 34 & 80 & 4 & 120 & 446 & \multirow[b]{2}{*}{600} \\
\hline & & $\%$ & 0 & 1,67 & 28,3 & \begin{tabular}{|l|}
66 \\
.7
\end{tabular} & $\begin{array}{l}3,3 \\
3\end{array}$ & 100 & 74,33 & \\
\hline \multicolumn{2}{|l|}{$\begin{array}{l}\text { Total } \\
\text { Percentas }\end{array}$} & & & & & & & & $\begin{array}{l}50,54 \\
70,54\end{array}$ & 5.400 \\
\hline
\end{tabular}


The expected score from the respondents concerning the Indonesian variable was 5,400. However, the calculation showed that the total value obtained was 3,809 ( $70.54 \%$ of the ideal score). This indicated that most respondents agreed Indonesian had shifted the language of communication. From the results, the BHS6 and BHS9 indicators had the highest score of $74.33 \%$, indicating that respondents understood information more easily when using Indonesian and used it more, specifically on social media.

\subsection{The Influence of Foreign Languages on Mother Tongue}

Foreign languages had the potential to shift the attitude of Betawi adolescents' towards their mother tongue. This is because foreign language is among the subjects taught in school, besides being considered prestigious. Table 5 presents nine indicators that describe the language attitudes of Betawi adolescents in responding to foreign languages.

Table 5.Respondents' Responses to Foreign Language Variables

\begin{tabular}{|c|c|c|c|c|c|c|c|c|c|c|}
\hline $\begin{array}{l}\text { Indicator } \\
\text { Code }\end{array}$ & Statement & $\frac{F}{\%}$ & STS & TS & RR & S & SS & Total & $\begin{array}{l}\text { Total } \\
\text { Score }\end{array}$ & $\begin{array}{l}\text { Ideal } \\
\text { Score }\end{array}$ \\
\hline \multirow{2}{*}{ BA1 } & \multirow{2}{*}{$\begin{array}{l}\text { Foreign languages show } \\
\text { my identity as a global } \\
\text { nation }\end{array}$} & F & 6 & 84 & 29 & 1 & 0 & 120 & 265 & \multirow{2}{*}{600} \\
\hline & & $\%$ & 5 & 70 & 24.2 & 0.83 & 0 & 100 & 44.17 & \\
\hline \multirow[b]{2}{*}{$\mathrm{BA} 2$} & \multirow{2}{*}{$\begin{array}{l}\text { Foreign language } \\
\text { vocabulary is a means of } \\
\text { daily communication in } \\
\text { the family }\end{array}$} & $\mathrm{F}$ & 5 & 72 & 35 & 8 & 0 & 120 & 286 & \multirow[b]{2}{*}{600} \\
\hline & & $\%$ & 4.17 & 60 & 29.2 & 6.67 & 0 & 100 & 47.67 & \\
\hline \multirow[b]{2}{*}{ BA3 } & \multirow{2}{*}{$\begin{array}{l}\text { The government carries } \\
\text { out the preservation of } \\
\text { foreign languages with } \\
\text { real programs }\end{array}$} & F & 6 & 52 & 53 & 9 & 0 & 120 & 305 & \multirow[b]{2}{*}{600} \\
\hline & & $\%$ & 5 & 43.3 & 44.2 & 7.5 & 0 & 100 & 50.83 & \\
\hline \multirow[b]{2}{*}{ BA4 } & \multirow{2}{*}{\begin{tabular}{|l|r|} 
I feel proud & if I \\
communicate & using \\
foreign & language \\
vocabulary & valu
\end{tabular}} & $F$ & 4 & 69 & 43 & 4 & 0 & 120 & 287 & \multirow[b]{2}{*}{600} \\
\hline & & $\%$ & 3.33 & 57.5 & 35.8 & 3.33 & 0 & 100 & 47.83 & \\
\hline \multirow[b]{2}{*}{ BA5 } & \multirow{2}{*}{$\begin{array}{l}\text { I find it easier to master } \\
\text { forign language } \\
\text { vocabulary than Betawi } \\
\text { and Indonesian }\end{array}$} & F & 21 & 64 & 29 & 6 & 0 & 120 & 260 & \multirow[b]{2}{*}{600} \\
\hline & & $\%$ & 17.5 & 53.3 & 24.2 & 5 & 0 & 100 & 43.33 & \\
\hline \multirow[b]{2}{*}{ BA6 } & \multirow{2}{*}{$\begin{array}{l}\text { It is easier for me to } \\
\text { understand information } \\
\text { if I use foreign language } \\
\text { vocabulary }\end{array}$} & $\mathrm{F}$ & 26 & 69 & 25 & 0 & 0 & 120 & 239 & \multirow[b]{2}{*}{600} \\
\hline & & $\%$ & 21.7 & 57.5 & 20.8 & 0 & 0 & 100 & 39.83 & \\
\hline \multirow[b]{2}{*}{ BA7 } & \multirow{3}{*}{$\begin{array}{l}\text { I use foreign language } \\
\text { vocabulary more often in } \\
\text { communicating with my } \\
\text { family }\end{array}$} & $\mathrm{F}$ & 19 & 74 & 27 & 0 & 0 & 120 & 248 & \multirow[b]{2}{*}{600} \\
\hline & & $\%$ & 15.8 & 61.7 & 22.5 & 0 & 0 & 100 & 41.33 & \\
\hline \multirow[b]{2}{*}{ BA8 } & & $\mathrm{F}$ & 9 & 77 & 24 & 7 & 3 & 120 & 278 & \multirow[b]{2}{*}{600} \\
\hline & $\begin{array}{l}\text { I use foreign language } \\
\text { vocabulary more often in } \\
\text { communicating formal } \\
\text { situations }\end{array}$ & $\%$ & 7.5 & 64.2 & 20 & 5.83 & 2.5 & 100 & 46.33 & \\
\hline \multirow[b]{2}{*}{ BA9 } & \multirow{2}{*}{$\begin{array}{l}\text { I often use foreign } \\
\text { language vocabulary in } \\
\text { interacting in } \\
\text { media }\end{array}$} & $\mathrm{F}$ & 4 & 77 & 27 & 9 & 3 & 120 & 290 & \multirow[b]{2}{*}{600} \\
\hline & & $\%$ & 3.33 & 64.2 & 22.5 & 7.5 & 2.5 & 100 & 48.33 & \\
\hline \multicolumn{2}{|c|}{$\begin{array}{l}\text { Total } \\
\text { Percentage }\end{array}$} & & & & & & & & \begin{tabular}{|l|}
2,458 \\
45.52
\end{tabular} & 5,400 \\
\hline
\end{tabular}

The expected score from the responses on questionnaire statements regarding foreign language variables was 5,400. However, the calculation showed that the total value obtained was $2,458(45.52 \%)$ of the ideal score. This indicated that most Betawi adolescents did not agree that foreign languages could replace their mother tongue.

\subsection{Descriptive Statistics Test Results}

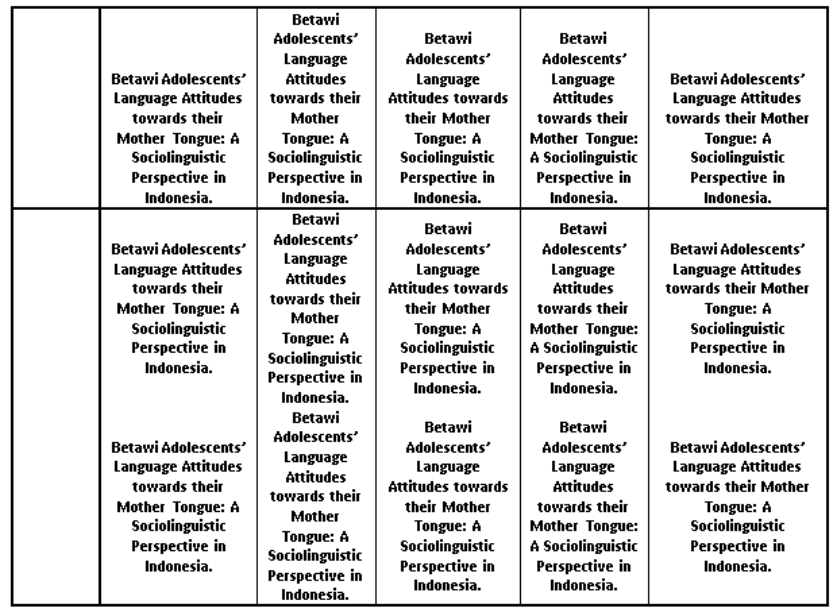

The results showed that the attitude variable had a maximum value of 3.27 and a minimum value of 1.00 with an average of 2.0253. This indicated that, on average, the language attitude of Betawi adolescents' towards their mother tongue was negative.

The variable attitude of Betawi adolescents' towards Indonesian shifted their mother tongue to have a maximum value of 4.89 and a minimum value of 1.78 with an average of 3.5273. This indicated that, on average, the Indonesian was able to shift the mother tongue.

Furthermore, the attitude of Betawi adolescents towards foreign languages variable shifted the mother tongue to have a maximum value of 3.56 and a minimum value of 1.33 with an average of 2.2760 . This showed that foreign languages could not influence the mother tongue shift.

Table 6. Descriptive Statistics

\begin{tabular}{|l|l|l|l|l|l|}
\hline Attitude & $\mathrm{N}$ & Min & Max & Mean & $\begin{array}{l}\text { Std. } \\
\text { Deviation }\end{array}$ \\
\hline Indonesia & 120 & 1.00 & 3.27 & 2.0253 & .49546 \\
\hline Foreign & 120 & 1.78 & 4.89 & 3.5273 & .52200 \\
\hline $\begin{array}{l}\text { Valid N } \\
\text { (listwise) }\end{array}$ & 120 & 1.33 & 3.56 & 2.2760 & .47831 \\
\hline
\end{tabular}

\section{CONCLUSIONS AND SUGGESTIONS}

The attitude of Betawi adolescents towards their mother tongue was negative in all aspects, including cognitive, affective, and conative. Furthermore, the results showed that $70.54 \%$ of the respondents agreed that Indonesian affected shifting their mother tongue. Besides, less than half of the respondents (45.52) agreed that a foreign language affected shifting their mother tongue. 
Based on the conclusions, the following two suggestions were conveyed. First, parents should massively teach their children the local language, specifically when at home. Second, the local governments should take concrete actions towards promoting mother tongues by issuing laws and regulations and implementing them with programs such as providing sufficient budget for mother-tongue preservation activities, specifically in schools. Additionally, it should be used as the language of school instruction in the early grades of elementary school, as well as making local content subjects in junior and senior high schools.

\section{AUTHORS' CONTRIBUTIONS}

In this research the author was assisted by two teams, namely the data collection team and the data processing team. The data collection team is tasked with helping the author to collect data using a questionnaire, while the data processing team assists the writer in processing the data using SPSS. The author analyzes the data and writes a research report in the form of an article.

\section{ACKNOWLEDGMENTS}

We would like to thank: Betawi community groups in five areas of Jakarta who have helped collect the required data, Betawi Cultural Institute for providing very useful references, Jakarta Scholarships for providing research funding, and other parties who have supported this research.

\section{REFERENCES}

[1] Triandis, Marry C. (1971). Attitude and Attitude Change, New York: John Wiley \& Sons, Inc.

[2] Lukman. (2012). Vitalitas Bahasa : Pergeseran dan Pemertahanan Bahasa, Makassar: de La Macca.

[3] Lambert, W.E.(1967). A Social Psychology of Bilingualism. Journal of Social Issues.

[4] Sarwono, Sarlito W. (2011). Psikologi Remaja. Jakarta: Rajawali.

[5] Love, N., \& Ansaldo, U. (2010). The native speaker and the mother tongue. LanguageSciences, 32(6), 589-593.

[6] Carter, E., Sabates, R., Rose, P., \& Akyeampong, K. (2020). Sustaining literacy from mother-tongue instruction in complementary education into an official language of instruction in government schools in Ghana. International Journal of Educational Development. 